\title{
THE
}

\section{(Un)Sustainability and Organization Studies: Towards a Radical Engagement}

Seray Ergene

University of Rhode Island, serayergene@uri.ed

Bobby S. Banerjee

Andrew J. Hoffman

Follow this and additional works at: https://digitalcommons.uri.edu/cba_facpubs

\section{The University of Rhode Island Faculty have made this article openly available.}

Please let us know how Open Access to this research benefits you.

This is a pre-publication author manuscript of the final, published article.

Terms of Use

This article is made available under the terms and conditions applicable towards Open Access

Policy Articles, as set forth in our Terms of Use.

\section{Citation/Publisher Attribution}

Ergene, S., Banerjee, S. B., \& Hoffman, A. (2020). Author Accepted Manuscript: (Un)Sustainability and Organization Studies: Towards a Radical Engagement. Organization Studies. https://doi.org/10.1177/ 0170840620937892

Available at: https://doi.org/10.1177/0170840620937892 


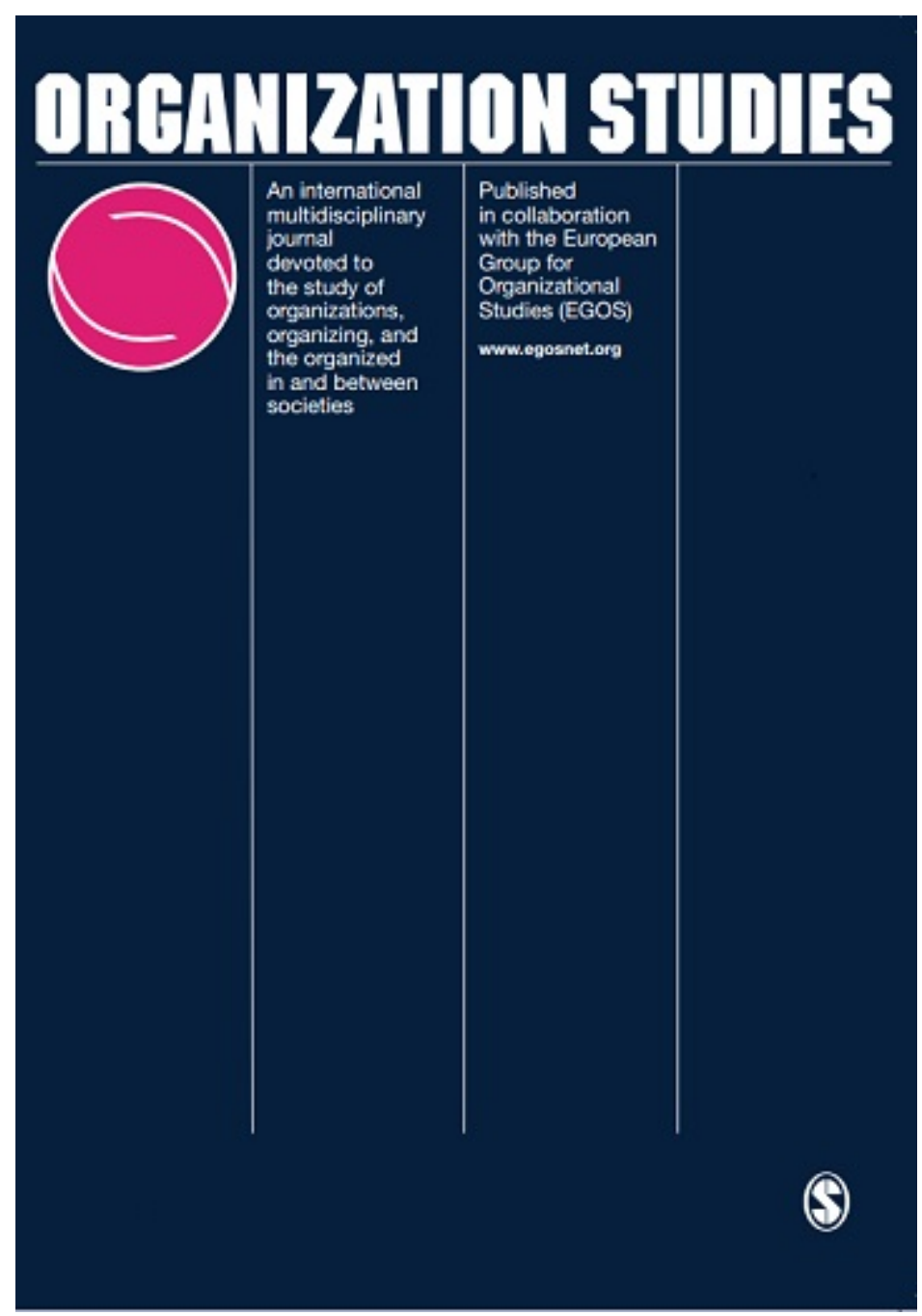

(Un)Sustainability and Organization Studies: Towards a Radical Engagement

\begin{tabular}{|c|c|}
\hline Journal: & Organization Studies \\
\hline Manuscript ID & OS-19-0498.R3 \\
\hline Manuscript Type: & $\mathrm{X}$ and Organization Studies \\
\hline Keywords: & $\begin{array}{l}\text { Sustainability, Anthropocene, Epistemology, Ontology, Interdisciplinarity, } \\
\text { Engaged scholarship }\end{array}$ \\
\hline Abstract: & $\begin{array}{l}\text { In this essay, we trace the evolution of the field of sustainability in } \\
\text { management and organization studies and narrate its epistemological } \\
\text { twists and turns. Concerned by the current trajectory that tends to } \\
\text { diminish a focus on political concerns, we propose a new research } \\
\text { agenda, ecological case for business, that transforms our paradigmatic } \\
\text { orientation in four shifts: } 1 \text { ) altering our epistemological lenses from } \\
\text { managerial to critical perspectives, } 2 \text { ) altering our ontological lenses }\end{array}$ \\
\hline
\end{tabular}


from realist to relational view, 3) changing the way we design and conduct research from discipline-focused to interdisciplinary knowledge, and 4) transforming our scholarly stance from value-neutral to engaged scholarship. We argue that these shifts have capacities to overcome the conceptual limitations of the business case, and more fundamentally, help us question our scholarly positioning to the ongoing socio-ecological crises.

\section{SCHOLARONE ${ }^{\text {m }}$ \\ Manuscripts}




\title{
(Un)Sustainability and Organization Studies:
}

Towards a Radical Engagement

\author{
Seray Ergene \\ College of Business \\ University of Rhode Island \\ serayergene@uri.edu \\ Bobby S Banerjee \\ Cass Business School \\ City University of London \\ Bobby.Banerjee.1@city.ac.uk \\ Andrew J Hoffman \\ Ross School of Business \\ University of Michigan \\ ajhoff@umich.edu
}

\section{Corresponding author:}

Seray Ergene, College of Business, University of Rhode Island, Kingston, RI 02881 serayergene@uri.edu, +1 (401) 874-4390. 


\title{
(Un)Sustainability and Organization Studies: Towards a Radical Engagement
}

\begin{abstract}
:
In this essay, we trace the evolution of the field of sustainability in management and organization studies and narrate its epistemological twists and turns. Concerned by the current trajectory that tends to diminish a focus on political concerns, we propose a new research agenda, ecological case for business, that transforms our paradigmatic orientation in four shifts: 1) altering our epistemological lenses from managerial to critical perspectives, 2) altering our ontological lenses from realist to relational view, 3) changing the way we design and conduct research from discipline-focused to interdisciplinary knowledge, and 4) transforming our scholarly stance from value-neutral to engaged scholarship. We argue that these shifts have capacities to overcome the conceptual limitations of the business case, and more fundamentally, help us question our scholarly positioning to the ongoing socio-ecological crises.
\end{abstract}

\section{Key words:}

Sustainability, Anthropocene, Epistemology, Ontology, Interdisciplinarity, Engaged scholarship 


\section{(Un)Sustainability and Organization Studies: Towards a Radical Engagement}

"We have become, by the power of a glorious evolutionary accident called intelligence, the stewards of life's continuity on earth. We did not ask for this role, but we cannot abjure it. We may not be suited to it, but here we are.” (Gould, 1985, p. 431)

As Gould makes clear, humanity is facing a new ecological responsibility for which it is unfamiliar and unprepared. Climate change, species extinction, and ocean acidification are just some of the markers of what scientists call the Anthropocene, a geological period characterized by a dominant human influence on the functioning of the ecosystem. At the same time, it is important to problematize who the "we" are because the dangerous ecological conditions we all face today are the product of particular political and economic policies and practices aimed at exploiting nature for the benefit of a few. The Anthropocene is not a story of unintended consequences but is a direct result of a political economy that privileges wealth accumulation at the expense of environmental destruction. In fact, some have proposed that the term "Anthropocene" should be replaced by the term "Capitalocene" (Moore, 2016) or "Econocene" (Norgaard, 2013) to indicate the almost divine status of markets, and "Technocene" (Hornborg, 2015) or "Plutocene" (Glikson, 2017) to represent the gross inequalities in material consumption and greenhouse gas emissions.

Unfortunately, our prevalent discourses and practices around sustainability carry such political and economic premises, and they limit our abilities to think and act outside of existing approaches. As scholars researching and teaching sustainability related phenomena in business schools, we are disturbed by the dominant business case orientation of our scholarship on environmental and social issues. In this essay, we aim to unsettle the field's direction ${ }^{1}$ and $\operatorname{argue}^{\prime}$ 
for its paradigmatic transformation to foster a radical scholarship that can enable a more meaningful engagement with the ongoing socio-ecological devastation.

Acknowledging the importance of corporate practices on the stability of our natural environment, there has been a potent effort to examine how business organizations impact the natural world through a research domain called "business and the natural environment", which started in the early 1990s. With its subsequent reorientation around "business sustainability" in the 2000s, the corporate influence on the social world has been added to the research effort. However, despite its growing success in gaining legitimacy, its analytic approaches are not equipped to handle the grand challenges of the Anthropocene, which are fundamentally about survival of human and nonhuman life on Earth and preventing socio-economic inequalities. While seeking ways to "green" or make organizations "sustainable", the field has failed to pay attention to the root issues that produce our present crises. The existing literature has focused predominately on incremental change without problematizing its political-economic premises, ${ }^{2}$ yet the problems of the Anthropocene requires transformational change at the systemic level that re-considers how humans relate to the natural world and how wealth is distributed among diverse populations.

In this paper, we make this case, explaining why this may be so and how we might redirect the field's emphasis to focus more directly on the root of the sustainability challenge. To do that, we first offer a brief history of sustainability and the natural environment in organization studies, covering its origins in the 1990 s, its evolution into sustainability in 2000 s and its present state. Further, we discuss the two epistemologies that marked the field's origins - critical and managerial - and show how the managerial view took precedence by gaining legitimacy within the political institutions of academia. ${ }^{3}$ As concerned scholars of organization studies, we argue 
that we must re-consider our intellectual approaches and propose a new research agenda, one that foregrounds the political and that has capacities to engage with our ongoing socio-ecological collapse. Specifically, we call for four fundamental shifts that act as political interventions to transform the prevailing business case orientation and to prompt research for an ecological case for business. These shifts are: (1) from managerial to critical epistemologies, (2) from realist to relational ontologies, (3) from discipline-focused to interdisciplinary collaborations with natural sciences, and (4) from value-neutral stance to engaged scholarship. We close our essay with a challenge for scholars - to redirect one's field of inquiry towards addressing the systemic causes of our environmental problems even if that means moving in a direction that is contrary to the political, economic and academic institutions in which we reside.

\section{A brief history of (un)sustainability in organization studies}

While some studies on the natural environment in management can be traced back to the beginning of the modern environmental movement in the 1970s (i.e., Gladwin \& Welles, 1976), the topic did not become an object of significant research interest until the early-1990s with the first efforts to build a research community among management scholars (e.g., the Greening of Industry Network in 1989 and the Organizations and the Natural Environment special interest group of the Academy of Management in 1994, later to become a division in 2007) and the creation of academic journals dedicated to the interface between managerial action and environmental protection (e.g., Organization \& Environment which was created in 1987 from its predecessor Industrial Crisis Quarterly, and Business Strategy \& the Environment in 1991.4 


\section{The original agenda of organizations and the natural environment research}

Much of the early work on organizations and the natural environment was fragmented and diverse, driven by scholars who were concerned about environmental dangers like the Bhopal disaster in 1984, the discovery of the Ozone Hole in 1985, and the Exxon Valdez oil spill in 1989. Given the rising concerns about corporate complicity in environmental harm, the topic could no longer be considered outside the realm of management research but compelled a shift in corporate posture from a reactive to a more proactive approach to environmental issues in the 1990s. Driving forces for this shift included enhanced corporate reputation, lower compliance costs and stronger competitive advantage in markets in the US and globally (Banerjee, 2001; Hoffman, 2001; Schmidheiny, 1992). While the natural environment became a focus of business research in 1990s (Hoffman \& Bansal, 2012), it remained on the fringes of management and organizational scholarship (Ehrenfeld \& Hoffman, 2013) with a focus on "greening organizations" (Shrivastava \& Hart, 1994) to study the intersection of managerial and environmental concerns. As the field began to develop, research took two epistemological perspectives: critical and managerial.

Critical epistemological research. This stream offered a critique of corporations' role in environmental degradation (Gladwin, Kennelly, \& Krause, 1995; Stead \& Stead, 1994; Welford, 1997). Paralleling developments in environmental sociology, this work viewed environmental pollution as a negative consequence of the dominant economic paradigm and called for a fundamental restructuring of economic and political systems (Schnaiberg, 1980). Building on the “new ecological paradigm" (Catton and Dunlap, 1980), Gladwin and his colleagues proposed that "modern management theory is constricted by a fractured epistemology, which separates humanity from nature and truth from morality" and concluded with the provocation that 
management theory should act "as if sustainability, extended community, and our Academy mattered" (Gladwin et al., 1995, p. 874).

Other early critical works argued that the dominant economic focus of management and organizational research prevented genuine engagement with ecological issues because the managerial and human-centered premises underlying organization theory and strategic management tended to rely on a profit motive that prioritized the interests of shareholders and managers (Shrivastava, 1994), perpetuated endless consumption-based economic growth (Purser, Park, \& Montuori, 1995), created asymmetrical wealth distribution in societies (Levy, 1997) and focused primarily on the needs of consumers and corporations from the Global North while denying the interests of marginalized populations (Banerjee, 2003). The central theme of this critical stream was that environmental issues were inseparable from political corporate interests and addressing them required challenging the political-economic premises of existing management frameworks.

Managerial epistemological research. This second stream integrated environmental concerns into existing theoretical frames of economic performance and profit maximization that the critical research found problematic. In this way, environmental issues became "strategic" in that they were related to corporate resources and capabilities, competitive advantage, organizational performance, stakeholder pressures, and institutional legitimacy (Buysse \& Verbeke, 2003; Russo \& Fouts, 1997).

A defining characteristic of the managerial research was its focus on corporate environmental strategies as a solution to environmental problems (Forbes \& Jermier, 2010). This research emphasized win-win market-based solutions where firms could reduce costs through energy efficiency, waste reduction and recycling initiatives or increase profits through a 
premium pricing strategy for green products. Focused on variants of the question, "Does it pay to be green?" this work sought to merge the drive for competitiveness with the demand for environmental protection as a means to gain economic advantage (Schmidheiny, 1992).

\section{Emergence of "sustainability" and mainstreaming of environmental research}

As the field continued to grow through the 1990s and 2000s, the managerial and critical streams both forwarded an imaginary of ecologically sustainable organizations and aimed to transform the dominant models of management and organization research. However, they were coming from different intellectual backgrounds, thus suggested different approaches to achieve sustainability. While the managerial works sought to integrate environmental issues into conventional corporate imperatives of profit maximization, the critical accounts acknowledged that economic activity was embedded in a larger network of political systems which privileged profitability over ecological sustainability.

Over the years the managerial perspective became the dominant paradigm, and in the mid-2000s, the terms "sustainable development" (Brundtland Commission, 1987) and "corporate sustainability" began to gain currency in redefining the field. Informed by the values of liberal humanism and Western environmentalism, this redefinition drew attention to fundamental social concerns including poverty, inequality, health and food insecurity in addition to the prior portfolio of environmental concerns upon which the field had devoted its attention. Corporate sustainability become the defining marker of the field to describe "the inclusion of social and environmental concerns in business operations and in interactions with stakeholders" (van Marrewijk \& Werre, 2003, p. 107). However, this new conception reinforced the managerial priorities that privileged economic growth, and suggested that sustainability could be achieved 
by corporate strategies and "sustainable" or "green" growth (Banerjee, 2011). More recent accounts have proposed "sustainable business models" that integrate stakeholder interests into value creation (Schaltegger et al., 2016). While this research seeks to facilitate radical transformation, it elides the contradictions between creating economic value for the firm and preventing unsustainable levels of resource extraction, material consumption, and asymmetrical wealth distribution at a systemic level.

As research on corporate sustainability became increasingly aligned with the dominant economic approach of the broader management field in the 2000s, environmental issues began to gain institutional legitimacy as a distinct area of management scholarship, one in which scholars could offer courses, publish in top-tier academic journals, secure tenure-track jobs and fill chaired professorships (Ehrenfeld \& Hoffman, 2013). Today, in business schools, most deans are supportive of sustainability curriculums under the umbrella of "responsible management education" (Forray \& Leigh, 2012), and a significant number of management courses include at least some coverage of corporate sustainability.

\section{Discrepancy between managerial research and socio-ecological system needs}

While research on corporate sustainability continues to proliferate, two worrying trends have emerged. One is the limits of corporate sustainability in addressing the root causes of the problems we face. For many, it has become nothing more than a label for actions or strategies that are actually driven by conventional economic principles of competitiveness and profitability (Jacobs, 1993). And while this dilution of the concept continues, the environmental and social problems that it is designed to address have worsened on a global scale. Climate change and the attendant emergence of the Anthropocene (IPCC, 2019) coupled with growing income inequality 
(Stiglitz, Fitoussi, \& Durand, 2019) are two over-riding systemic problems that are reaching epidemic proportions which the current dominant political- economy seems unable to address. The designer label of corporate sustainability proposes industry-focused technological fixes that do not respond to socio-ecological system needs (Dyllick \& Hockerts, 2002; Whiteman, Perego, \& Walker, 2013). Recycling, waste disposal, and energy efficiency only reduce unsustainability to a limited extent as they do not take into consideration ecosystem cycles and nature's regeneration capacity as well as negative impacts on disadvantaged populations. ${ }^{5}$

The systemic problems of climate change require more radical approaches, as the managerial approach will only slow the velocity at which we are heading towards a system collapse but will not change the trajectory of that inevitability (Ehrenfeld \& Hoffman, 2013). Mitigating harms and doing less bad will not be enough as these approaches still rely on the industrialized production and consumption towards the impossible goal of unlimited economic growth. While there are recent calls for moving beyond such a prevailing orientation (Bansal, 2019; Hahn, Figge, Aragón-Correa, \& Sharma, 2017), the analytical tools of corporate sustainability reinforce the managerial view and do not capture the contradictions of marketbased ideals and socio-ecological wellbeing, and therefore reproduce the illusion that we can pursue unlimited economic growth while managing the natural environment and creating equitable societies.

At this critical juncture, the field of business sustainability must reengage with radical approaches that explore the systemic basis of our sustainability challenges. The Anthropocene is not simply an environmental problem to be managed; rather it points to systemic breakdowns. Human systems are now dominating natural systems with disastrous effects as sea-level rise, ocean acidification, and species extinction make clear. At the same time, economic and political 
systems have become skewed towards the interests of the elites, to the exclusion of those who suffer its pernicious effects (Gilens \& Page, 2014). Solving these issues requires deeper questions about power relations, "Who gets to set the rules? What values should they reflect? What's fair? What do we owe to one another? - and reshape our society accordingly" (Stiglitz, quoted in Kehoe, 2016).

\section{Climate change and the Anthropocene: The move towards radical approaches}

Scientists have set a boundary limit for atmospheric $\mathrm{CO}_{2}$ at $350 \mathrm{ppm}$ to maintain a stable environment and we are now over 400 ppm and climbing (NOAA, 2020). These elevated concentrations are increasing the frequency and intensity of wildfires, droughts, hurricanes, temperature fluctuations, sea-level rise and more. But climate change is one marker of a more expansive systemic shift that scientists believe represents a new geologic epoch. Scientists have proposed that we have left the Holocene and entered the Anthropocene - the Age of Humans - to note the dominating influence that the world's 7.5 billion people (10 billion by 2050), are having on the planet (Crutzen \& Stoermer, 2000; Zalasiewicz et al., 2016). To empirically describe this shift, scientists have identified nine "planetary boundaries," (Rockström et al., 2009) which represent "thresholds below which humanity can safely operate and beyond which the stability of planetary-scale systems cannot be relied upon” (Gillings \& Hagan-Lawson, 2014, p. 2). Nine interrelated dimensions have identified: climate change, ocean acidification, ozone depletion, atmospheric aerosol loading, phosphorous and nitrogen cycles, global freshwater use, land system change, loss of biodiversity and chemical pollution. Four have already been exceeded: climate change, biodiversity loss, land system change, and the biogeochemical flows. And one is on the mend: ozone depletion (Steffen et al., 2015). More recently, scientists are considering a 
"Hothouse Earth" scenario when ecological changes create self-reinforcing effects that may intensify the disruption at a much faster rate than current prediction (Steffen et al., 2018). As these markers make clear, the Anthropocene is not an environmental problem like those we have faced in the past. It is a systemic failure of our dominant political-economy which maintains the conditions for unlimited raw material extraction, energy use, material consumption and waste releases in a continuous pursuit of profits and economic growth.

These dangerously unsettling realities make clear that 30 years of research on corporate sustainability has had only modest impact on shifting the course of society's damage to the natural and social worlds. While academic studies are not designed to provide direct contributions to practice, there is a growing pressure for scholars to provide useful analytic tools that could help students and future decision-makers organize sustainable socio-ecosystems. The rising tide of research produced by the dominant management paradigm on "whether it pays to be green" does not lift all boats but instead drowns all alternatives by reinforcing the very managerial priorities that created the environmental and social problems in the first place. As such, the solutions it proposes will be unable to achieve the ends it seeks.

The field's present course, which promotes incremental change without questioning the political-economic system that is responsible for the current crisis, cannot lead to novel conceptualizations necessary to create sustainable organization-environment relations. It is time to move beyond the narrow focus on the business case and alter the field's orientation towards new ways of organizing around systems thinking (Whiteman et al., 2013), sufficiency and degrowth (Banerjee, Jermier, Peredo, Perey, \& Reichel, 2019). To facilitate this change, we propose a new agenda that is equipped to handle current alarming ecological and social conditions. 6 


\section{Towards an ecological case for business in the Anthropocene}

To capture the full scope of the Anthropocene, we argue for a radical agenda that takes us beyond traditional theories, models and frameworks and that problematizes the foundational principles of our current political economy. What if we were to take socio-ecological wellbeing as our central focus, and make an ecological case for business, instead of the business case for sustainability $?^{7}$ Flipping the words is not a linguistic sleight of hand but requires a paradigmatic transformation of our intellectual field. Fundamentally, it compels the foregrounding of the political in our scholarly endeavors and the justification of organizations' existence based on socio-ecological needs instead of economic growth aspirations. To facilitate such transformation in management and organization studies (MOS), we propose four shifts that can act as political interventions and initiate productive conversations for future research. While all four shifts are necessary and ought to be pursued in tandem in order to fully embrace the ecological case, they are neither an exhaustive list nor a finished template. Rather, these shifts are a few important initial steps that will dislocate the naturalized business case orientation and foster research for socio-ecological wellbeing.

\section{From managerial to critical epistemologies}

Drawing on insights from early accounts of critical epistemologies, the first shift we propose is from managerial interests to vital concerns that have become marginalized in business sustainability research (Ergene, Calás, \& Smircich, 2018; Wright, Nyberg, Rickards, \& Freund, 2018). Broadly, this would entail transforming our analytic attention to matters that are fundamental to ecological wellbeing and environmental justice, in order to create alternative 
forms of organizing that channel efforts for building livable ecologies for all in the Anthropocene. (See Table 1).

Insert Table 1

Addressing environmental and social problems in the Anthropocene requires the acknowledgment that our current political economy, which is based on consumption-based economic growth, competitive relations, shareholder wealth and exploitation of nature, privileges wealth accumulation at the expense of environmental destruction and social equity. Ultimately, the Anthropocene is a result of an economic capture of nature and represents a story of domination. To recover what has been lost, political struggles for environmental justice must be central to our inquiries. In this regard, the analytic tools of critical management studies are helpful for articulating different forms of domination and exploitation and problematizing those premises (Adler, Forbes, \& Willmott, 2007). There are various intellectual traditions, each emphasizing different modes of power, such as capitalist, colonial, patriarchal, discursive, and others. A critical research agenda aims to transform existing power relations and to envision new possibilities of organizing economies and societies (Zanoni, Contu, Healy, \& Mir, 2017).

While we suggest ecological and social concerns as a focus for future research, we are not proposing to reject the study of corporations and industry altogether. On the contrary, we think that management and organization studies are well-positioned to pay close attention to the negative consequences of industrial production and consumption. Studies from within organizations can help us critically analyze sustainability solutions forwarded by the industry and identify their limits in order to incorporate those insights for formulating viable alternatives. ${ }^{8}$ Instead of asking "whether it pays to be green," future research from critical epistemologies 
would ask whether the proposed green solutions are sufficient to create livable human-Earth ecologies where access to clean water and air, and arable land are available for all populations regardless of wealth and other social disparities.

\section{From realist to relational ontologies}

The Anthropocene makes visible the ecological destruction of our human-centered lifestyles and industrialized consumption habits. Earlier accounts had suggested that the main premise of industrialism and much of our consumption-based living rely on a conceptual separation of humans from the rest of nature and the positioning of our species as the controller of nature (Purser et al., 1995; Shrivastava, 1994). Overcoming such an anthropocentric basis of our theories requires new analytic capabilities that can bring focus to planetary-scale humanEarth relations. To foster research that begins from the socio-ecological needs and to facilitate theorizing novel ways of relating to nature, our second proposal is an ontological shift towards a relational view of the world (e.g., Bergson, 1907; Deleuze \& Guattari, 1987; Whitehead, 1929). (See Table 2)

Insert Table 2

Relational ontologies conceive the world as made up of complex and contingent webs of entanglements, and the analytic focus is on unfolding practices through which these relations are produced (Helin, Hernes, Hjorth, \& Holt, 2014). This view does not discern human and nonhuman entities in describing or explaining phenomena; rather it is the relations of humans and nonhumans (e.g., animals, plants, rocks, nitrogen, carbon, etc.) that co-constitute the world. Thus, relational ontologies allow us to theorize nature as a political subject, challenging the long- 
standing liberal humanist dichotomy of nature and culture (Kalonaityte, 2018). Relational philosophy also converses with various strands of environmental ethics. For instance, Deleuze and Guattari's “ecosophical subject” (Shaw, 2015), Whitehead's “ethics of creativity” (Henning, 2005), and Bergson's “creative evolution” (Simonetti, 2019) contribute to contemporary environmental thought, and provide foundations for conceptualizing different human-Earth relations (e.g., Gibson-Graham \& Roelvink, 2010; Tsing, 2015).

While the language of relational philosophy may appear abstract, there are clear examples that illustrate the politics and value of processual thinking for sustainability research (e.g., Heikkurinen et al., 2019; Newton, 2002). For example, Beacham (2018) brought attention to the shifting biogeochemical flows in soil due to heavy use of chemical fertilizers in industrialized agriculture. By unpacking the entanglements of human and material elements within the everyday practices of community supported agriculture, he illustrated that it is possible to develop a more-than-human ethics of care in growing food if we avoid imposing human timescales over nature's temporality. As this example shows, relational ontologies offer analytic capabilities to unentangle planetary-scale socio-ecological dynamics within practices and guide us to imagine human-Earth relations that respect nature's temporality and regeneration capacity.

\section{From discipline-focused to interdisciplinary collaborations with the natural sciences}

Current ecological conditions have produced irreversible changes for life on earth, with many species facing extinction due to unprecedented rapid changes in life-supporting ecosystems. At the same time, access to clean water and arable soil for crop growth are major concerns affecting many communities. These extraordinary challenges require us to learn the 
nature-human ecosystem functioning and ground MOS research on the interdependency of ecological and sociocultural systems. In this purpose, our third proposal calls for a shift from discipline-focused to interdisciplinary collaborative research with the natural sciences (see Table 3).

Insert Table 3

We are not alone nor the first ones to propose this shift. There have been several accounts that called for a deeper engagement with the earth sciences and "infuse management theory with biophysical foundations" (Starik \& Kanashiro, 2013, p. 14). Scholars have introduced key concepts from the field of ecology (Winn \& Pogutz, 2013), called attention to planetary boundaries in management research (Whiteman et al., 2013), proposed developing "climate social science" (Skoglund, 2015), and argued for a science-based approach that focuses attention on dangerous changes in the Arctic (Whiteman \& Yumashev, 2018).

However, there are several institutional and political impediments that need to be recognized. Most fundamentally, the ontological and epistemological differences between the assumptions underlying natural and social sciences create political tensions for which questions to ask and how we study them. At most universities, social scientists are seen as "supporting" faculty rather than the core, and face legitimacy challenges in interdisciplinary projects. Also, the evaluation parameters for tenure and promotion are narrowly based on contribution to disciplinary literatures, penalizing early career scholars who are willing to pursue interdisciplinary projects that require much more effort to coordinate and translate different forms of knowledge across disciplines (Felt, Igelsböck, Schikowitz, \& Völker, 2016). 
Despite these challenges, exemplary projects show how such efforts can succeed (e.g., Tsing, Swanson, Gan, \& Bubandt, 2017). We are seeing more calls for interdisciplinary knowledge production in journals to bridge ecological knowledge with organization studies (Wasieleski, Waddock, Fort, Costa, \& Metz, 2017). While we join these calls, we do not mean to cast a role for ourselves as "managers of the technoscientific solutions". On the contrary, we call on MOS to demonstrate climate science literacy and join interdisciplinary project teams as critical thinkers who would bring focus to the diverse interests and priorities, most importantly, of immediate community and disadvantaged groups. At the same time, due to the above mentioned challenges, such research must be reflexive and acknowledge the political processes involved in conducting interdisciplinary research with natural sciences.

\section{From value-neutral stance to engaged scholarship}

Early research on environmental issues reflected personal concerns of scholars who explicitly acknowledged that the natural environment was a "value-laden topic" (Gladwin et al., 1995, p. 878). While such questioning guided the initial orientation of the early works, the field has evolved within the prevalent positivist paradigm that encouraged conducting research from a disinterested stance. Unfortunately, such an arms-length approach limited passionate scholarship, which could help overcome the preoccupation with making the business case for sustainability. The Anthropocene conditions through which we currently live are undeniably material and are not captured by existing MOS theories. To shift our attention to these concrete conditions and begin research from within them, our fourth proposal is to reject the notion of a value-neutral science and embrace engaged scholarship in our academic endeavors (See Table 4).

Insert Table 4 
The expectation for dispassionate research is rooted in the principle of objectivity in positivism (Jones \& Bartunek, 2019). The disciplinary foundations of management knowledge were established within a positivist approach in order to claim rigor and achieve institutional legitimacy for the business school in the broader academy (Khurana, 2007). As in the natural sciences, business schools demanded replicable research that is conducted by inquirers who are "unbiased" and capable of producing "objective" knowledge that would preclude any personal values to influence research findings.

The value-free versus value-laden debate has a long history in social theory (Weber, 1949). While some argue that social theory is based on scientific facts that are independent of values (Campbell, 2014), others suggest that it is impossible to conduct value-neutral social science research (Gouldner, 1962). Although most journals in MOS favor value-free knowledge, there are calls for "engaged scholarship" that disrupts the narrative of a detached observer. Engaged scholarship begins with the assumption that "no form of inquiry is value-free and impartial" (Van de Ven, 2007, p.14), and is based on a relationship where researchers and participants co-produce knowledge about common concerns.

Taking a step further, other scholars have called for praxis interventions by academics to facilitate social change. For instance, Contu (2018) argues for reframing academic praxis towards an "intellectual activism", which is about making a stand and becoming accountable for putting our work in the service of social justice. According to Contu, intellectual activism not only involves researching marginalized concerns but also requires aligning teaching, service and leadership with social justice aims. In climate change debates, Rhodes, Wright, and Pullen (2018) suggest different modes of academic activism that can contribute to political 
transformation, such as media engagement, political campaigning, advising non-academics, and engaging in activist research. Other scholars argue for collaborating with influential decisionmakers, policy-makers, activists, think tanks, and NGOs to make interventions on the ground (Fleming \& Banerjee, 2016; Hoffman, 2016; Whiteman \& Yumashev, 2018). In short, these accounts call for re-thinking our scholarly position and role in society.

However, the institutionalized norms of the academia create disincentives for this transition. Evaluation norms and practices that prioritize "A" publications discourage engaged and activist oriented scholarship. Tenure and promotion are more influenced by journal impact factors than contributions to socio-ecological welfare in communities. But, to study an issue that is inflicting untold harm on present and future populations and nonhuman life forms without any concern for the implications of our work denies our humanity as scholars. Instead, management scholarship must develop a "political-academic" orientation that transforms our scholarly identity to becoming "politically engaged scholars” (Esper, Cabantous, Barin-Cruz, \& Gond, 2017, p. 681). Making ecological wellbeing and social justice the guiding compass of our field, we call for building broader connections in society that contribute to creating alternative modes of researching, organizing, and living as academic activists.

\section{Final notes on survival...}

"If our species does not survive the ecological crisis, it will probably be due to our failure to imagine and work out new ways to live with the earth, to rework ourselves and our high energy, high-consumption, and hyper-instrumental societies adaptively. [...] We will go onwards in a different mode of humanity, or not at all."

(Plumwood, 2007, p. 1) 
If our species is indeed worth saving, then the fundamental challenge of management and organization studies today is to delink our intellectual foundations from the hegemony of corporate thought. It is absurd that we continue to prioritize the financial bottom line when the very practices that contribute to it, such as the endless pursuit of economic growth, fueled by relentless resource extraction and mindless consumption, threaten the survival of the planet. Corporate capitalism, even with its much touted green credentials cannot deliver a sustainable and livable world. Demoting the centrality of the business case in our schools, our scholarship, and our society is another grand challenge as the spread of corporate values has been allencompassing. Yet, as management scholars concerned about environmental and social catastrophe, it is our responsibility to contribute to those efforts which challenge "the conceptual blockages that keep our minds closed to options for change" (Plumwood, 2007, p.1).

Transitioning to a new research agenda based on the ecological case for business requires learning to observe in new ways and asking different questions that facilitate imagining and creating new ways of living, going beyond market-based interests and anthropocentric concerns. It requires a deep look into our contribution as a field and learning to collaborate across disciplines and stakeholders to address the actual matters of concerns of our worlds. To facilitate such transition and create dialogue, in Table 5, we outline some broad research questions and action items.

\section{Insert Table 5}

The challenge of sustainability is not just economic, social, and environmental - it is fundamentally political in nature. It is our hope that the shifts we propose in this essay will facilitate developing a radical scholarship that is informed by new ways of relating to the natural 
world. Otherwise, we will run the risk of becoming the only species on the planet that is sufficiently intelligent to recognize our own imminent demise but too foolish to prevent it.

\author{
Notes \\ ${ }^{1}$ Emerging conversations that stand against the business case exist (e.g., sufficiency, de-growth, \\ and alternative organizing (Banerjee et al., 2019; Ergene et al., 2018; Wright et al., 2018)), but \\ mainly outside of mainstream journals. \\ ${ }^{2}$ Except some exemplary studies that do not adopt a managerial approach (e.g., Beacham, 2018; \\ Wright \& Nyberg, 2017; Zietsma \& Lawrence, 2010). \\ ${ }^{3}$ We rely on Burrell \& Morgan's (1979) description that epistemological assumptions are "about \\ the grounds of knowledge [...]. These assumptions entail ideas, for example, about what forms \\ of knowledge can be obtained, and how one can sort out what is to be regarded as 'true' from \\ what is to be regarded as 'false' "' (p.1). \\ ${ }^{4}$ Here we do not intend to offer a review of the literature. In this essay, our goal is to take \\ attention to the field's paradigmatic evolution and provoke scholars about the limitations of \\ existing conceptual approaches for research in the Anthropocene. For recent systematic reviews, \\ please see Bansal \& Song, 2017; Hahn et al., 2017. \\ ${ }^{5}$ Dyllick and Hockerts (2002) critiqued firms' sole focus on eco-efficiency and suggested six \\ criteria that must satisfied to claim sustainability: eco-effectiveness, socio-effectiveness, eco- \\ efficiency, socio-efficiency, sufficiency, and ecological equity. \\ ${ }^{6}$ While Millennium Development Goals Report (2015) presents improvements in social and \\ environmental markers, the conditions are still worsening at an alarming level (see e.g., UN \\ World Social Report (2020) and WWF Living Planet Report (2018)).
}


${ }^{7}$ Previous research raised similar questions, such as "How can business make an effective contribution to addressing the sustainability challenges we are facing?" (Dyllick \& Muff, 2016, p.156).

${ }^{8}$ For instance, Wright and Nyberg (2017) identified limitations of market responses, by studying the processes through which corporations' ambitious goals deteriorate over time.

\section{Acknowledgements}

We would like to thank the Senior Editor Charlene Zietsma and the three anonymous reviewers for their insightful guidance on the earlier versions of this manuscript. We also would like to thank the panelists of the 2018 Academy of Management session "Researcher's Guide to the Anthropocene: Learning from Foundations of ONE" for inspiring us to write this essay. 


\section{References}

Adler, P. S., Forbes, L. C., \& Willmott, H. (2007). Critical management studies. The Academy of Management Annals, 1, 119-179.

Banerjee, S. B. (2003). Who sustains whose development? Sustainable development and the reinvention of nature. Organization Studies, 24, 143-180.

Banerjee, S. B. (2011). Embedding sustainability across the organization: A critical perspective. Academy of Management Learning \& Education, 10, 719-731.

Banerjee, S. B. (2001). Managerial perceptions of corporate environmentalism: interpretations from industry and strategic implications for organizations. Journal of Management Studies, 38, 489-513.

Banerjee, S. B., Jermier, J. M., Peredo, A. M., Perey, R., \& Reichel, A. (2019). Cfp: Theoretical perspectives on organizations and organizing in a post-growth era. Organization, 1-7.

Bansal, P. (2019). Sustainable development in an age of disruption. Academy of Management Discoveries, 5, 8-12.

Bansal, P., \& Song, H.-C. (2017). Similar but not the same: Differentiating corporate responsibility from sustainability. Academy of Management Annals, 11, 105-149.

Beacham, J. (2018). Organising food differently: Towards a more-than-human ethics of care for the Anthropocene. Organization, 25, 533-549.

Bergson, H. (1907). Creative evolution. Lanham, MD: University Press of America.

Burrell, G., \& Morgan, G. (1979). Sociological paradigms and organisational analysis. UK: Heinemann.

Buysse, K., \& Verbeke, A. (2003). Proactive environmental strategies: A stakeholder management perspective. Strategic Management Journal, 24, 453-470. 
Campbell, B. (2014). Anti-minotaur: The myth of a sociological morality. Society, 51, 443-451.

Catton, W. R., \& Dunlap, R. E. (1980). A new ecological paradigm for post-exuberant sociology. American Behavioral Scientist, 24, 15-47.

Contu, A. (2018). '... The point is to change it' - Yes, but in what direction and how? Intellectual activism as a way of 'walking the talk' of critical work in business schools. Organization, 25, 282-293.

Crutzen, P. J., \& Stoermer, E. F. (2000). The Anthropocene. Global Change Newsletter, 41, 1718.

Deleuze, G., \& Guattari, F. (1987). A thousand plateaus: Capitalism and schizophrenia (B. Massumi, Trans.). Minneapolis: University of Minnesota Press.

Dyllick, T., \& Hockerts, K. (2002). Beyond the business case for corporate sustainability. Business Strategy and the Environment, 11, 130-141.

Dyllick, T., \& Muff, K. (2016). Clarifying the meaning of sustainable business: Introducing a typology from business-as-usual to true business sustainability. Organization $\&$ Environment, 29, 156-174.

Ehrenfeld, J. R., \& Hoffman, A. J. (2013). Flourishing: A frank conversation about sustainability. Stanford: Stanford University Press.

Ergene, S., Calás, M. B., \& Smircich, L. (2018). Ecologies of sustainable concerns: Organization theorizing for the Anthropocene. Gender, Work \& Organization, 25, 222-245.

Esper, S. C., Cabantous, L., Barin-Cruz, L., \& Gond, J.-P. (2017). Supporting alternative organizations? Exploring scholars' involvement in the performativity of workerrecuperated enterprises. Organization, 24, 671-699. 
Felt, U., Igelsböck, J., Schikowitz, A., \& Völker, T. (2016). Transdisciplinary sustainability research in practice: Between imaginaries of collective experimentation and entrenched academic value orders. Science, Technology, \& Human Values, 41, 732-761.

Fleming, P., \& Banerjee, S. B. (2016). When performativity fails: Implications for critical management studies. Human Relations, 69, 257-276.

Forbes, L. C., \& Jermier, J. M. (2010). The new corporate environmentalism and the ecology of commerce. Organization \& Environment, 23, 465-481.

Forray, J. M., \& Leigh, J. S. (2012). A primer on the principles of responsible management education: Intellectual roots and waves of change. Journal of Management Education, 36, 295-309.

Gibson-Graham, J. K. and Roelvink, G. (2010). An Economic Ethics for the Anthropocene, Antipode, 41, 320-46.

Gilens, M., \& Page, B. I. (2014). Testing theories of American politics: Elites, interest groups, and average citizens. Perspectives on Politics, 12, 564-581.

Gillings, M. R., \& Hagan-Lawson, E. L. (2014). The cost of living in the Anthropocene. Earth Perspectives, 1, 2.

Gladwin, T. N., Kennelly, J. J., \& Krause, T.-S. (1995). Shifting paradigms for sustainable development: Implications for management theory and research. Academy of Management Review, 20, 874-907.

Gladwin, T. N., \& Welles, J. G. (1976). Multinational corporation and environmental protection: Patterns of organizational adaptaion. International Studies of Management \& Organization, 6, 160-184. 
Glikson, A. Y. (2017). The plutocene: Blueprints for a post-Anthropocene greenhouse earth (Vol. 13). Switzerland: Springer.

Gould, S. J. (1985). The flamingo's smile: Reflections in natural history. London: W. W. Norton \& Company.

Gouldner, A. W. (1962). Anti-minotaur: The myth of a value-free sociology. Social Problems, 9 , 199-213.

Hahn, T., Figge, F., Aragón-Correa, J. A., \& Sharma, S. (2017). Advancing research on corporate sustainability: Off to pastures new or back to the roots? Business \& Society, 56, 155-185.

Helin, J., Hernes, T., Hjorth, D., \& Holt, R. (2014). The Oxford handbook of process philosophy and organization studies. UK: Oxford University Press.

Henning, B. G. (2005). The ethics of creativity: Beauty, morality, and nature in a processive cosmos. PA: University of Pittsburgh Press.

Heikkurinen, P., Clegg, S., Pinnington, A. H., Nicolopoulou, K., \& Alcaraz, J. M. (2019). Managing the Anthropocene: Relational agency and power to respect planetary boundaries. Organization \& Environment, 1086026619881145.

Hoffman, A. J. (2001). From heresy to dogma: An institutional history of corporate environmentalism. Stanford: Stanford University Press.

Hoffman, A. J. (2016). Reflections: Academia's emerging crisis of relevance and the consequent role of the engaged scholar. Journal of Change Management, 16, 77-96.

Hoffman, A. J., \& Bansal, P. (2012). Retrospective, perspective, and prospective: Introduction. In The Oxford handbook of business and the natural environment (pp. 3-25). Oxford: Oxford University Press. 
Hornborg, A. (2015). The political ecology of the technocene: Uncovering ecologically unequal exchange in the world-system. In The Anthropocene and the Global Environmental Crisis (pp. 57-69). New York: Routledge.

IPCC. (2019). Special Report on climate change and land. Retrieved from https://www.ipcc.ch/srccl/

Jacobs, M. (1993). The green economy: Environment, sustainable development and the politics of the future. Chicago: Pluto Press.

Jones, E. B., \& Bartunek, J. M. (2019). Too close or optimally positioned? The value of personally relevant research. Academy of Management Perspectives. https://doi.org/10.5465/amp.2018.0009

Kalonaityte, V. (2018). When rivers go to court: The Anthropocene in organization studies through the lens of Jacques Rancière. Organization, 25, 517-532.

Kehoe, J. (2016). Can capitalism be redeemed? Harvard Business Review, 94, 23.

Khurana, R. (2007). From higher aims to hired hands: The social transformation of American business schools and the unfulfilled promise of management as a profession. Princeton: Princeton University Press.

Levy, D. L. (1997). Environmental management as political sustainability. Organization \& Environment, 10, 126-147.

Moore, J. W. (2016). Anthropocene or Capitalocene?: Nature, history, and the crisis of capitalism. Oakland: PM Press.

Newton, T. J. (2002). Creating the new ecological order? Elias and actor-network theory. Academy of Management Review, 27, 523-540. 
NOAA. (2020). Trends in atmospheric carbon dioxide. Retrieved April 19, 2020, from https://www.esrl.noaa.gov/gmd/ccgg/trends/

Norgaard, R. B. (2013). Escaping economism, escaping the econocene. In Economy of Sufficiency (pp. 44-52). Wuppertal Institute for Climate: Environment and Energy.

Plumwood, V. (2007). A review of Deborah Bird Rose's "Reports from a wild country: Ethics for decolonisation." Australian Humanities Review, 42, 1-4.

Purser, R. E., Park, C., \& Montuori, A. (1995). Limits to anthropocentrism: Toward an ecocentric organization paradigm? Academy of Management Review, 20, 1053-1089.

Rhodes, C., Wright, C., \& Pullen, A. (2018). Changing the world? The politics of activism and impact in the neoliberal university. Organization, 25, 139-147.

Rockström, J., Steffen, W., Noone, K., Persson, Å., Chapin, F. S., Lambin, E. F., ... Foley, J. A. (2009). A safe operating space for humanity. Nature, 461, 472-475.

Russo, M. V., \& Fouts, P. A. (1997). A resource-based perspective on corporate environmental performance and profitability. Academy of Management Journal, 40, 534-559.

Schaltegger, S., Hansen, E. G., \& Lüdeke-Freund, F. (2016). Business models for sustainability: Origins, present research, and future avenues. Organization \& Environment, 29, 3-10. Schmidheiny, S. (1992). Changing course: A global business perspective on development and the environment. Cambridge: MIT Press.

Schnaiberg, A. (1980). The environment, from surplus to scarcity. UK: Oxford University Press. Shaw, R. (2015). Bringing Deleuze and Guattari down to Earth through Gregory Bateson: Plateaus, rhizomes and ecosophical subjectivity. Theory, Culture \& Society, 7-8, 151171. 
Shrivastava, P. (1994). CASTRATED environment: GREENING organizational studies. Organization Studies, 15, 705-726.

Shrivastava, P., \& Hart, S. (1994). Greening organizations 2000. International Journal of Public Administration, 17, 607-635.

Simonetti, C. (2019). The petrified Anthropocene. Theory, Culture \& Society, 36, 45-66.

Skoglund, A. (2015). Climate social science-Any future for 'blue sky research' in management studies? Scandinavian Journal of Management, 31, 147-157.

Starik, M., \& Kanashiro, P. (2013). Toward a theory of sustainability management: Uncovering and integrating the nearly obvious. Organization \& Environment, 26, 7-30.

Stead, W. E., \& Stead, J. G. (1994). Can humankind change the economic myth? Paradigm shifts necessary for ecologically sustainable business. Journal of Organizational Change Management, 7, 15-31.

Steffen, W., Richardson, K., Rockstrom, J., Cornell, S. E., Fetzer, I., Bennett, E. M., ... Sorlin, S. (2015). Planetary boundaries: Guiding human development on a changing planet. Science, 347, 736-747.

Steffen, W., Rockström, J., Richardson, K., Lenton, T. M., Folke, C., Liverman, D., ... Schellnhuber, H. J. (2018). Trajectories of the Earth System in the Anthropocene. Proceedings of the National Academy of Sciences, 115, 8252-8259.

Stiglitz, J. E., Fitoussi, J.-P., \& Durand, M. (2019). Measuring what counts: A new dashboard for well-being. New Press.

Tsing, A. L. (2015). The mushroom at the end of the world: On the possibility of life in capitalist ruins. Princeton: Princeton University Press. 
Tsing, A. L., Swanson, H. A., Gan, E., \& Bubandt, N. (2017). Arts of Living on a Damaged Planet: Ghosts and Monsters of the Anthropocene. Minneapolis: University of Minnesota Press.

Van de Ven, A. H. (2007). Engaged scholarship: A guide for organizational and social research. Oxford: Oxford University Press.

van Marrewijk, M., \& Werre, M. (2003). Multiple levels of corporate sustainability. Journal of Business Ethics, 44, 107-119.

Wasieleski, D., Waddock, S., Fort, T., Costa, N. G.-D., \& Metz, N. (2017). CFP Special Issue: Natural science approaches toward transformational change for sustainability. Business \& Society.

Weber, M. (1949). Methodology of social sciences (E. A. Shils \& H. Finch, Trans.). Illinois: The Free Press.

Welford, R. (1997). Hijacking environmentalism: Corporate responses to sustainable development. UK: Earthscan.

Whitehead, A.N. (1929). Process and Reality. An Essay in Cosmology. UK: Cambridge University Press.

Whiteman, G, Perego, P., \& Walker, B. (2013). Planetary boundaries: Ecological foundations for corporate sustainability. Journal of Management Studies, 50, 307-336.

Whiteman, G., \& Yumashev, D. (2018). Poles apart: The arctic \& management studies. Journal of Management Studies, 55, 873-879.

Winn, M. I., \& Pogutz, S. (2013). Business, ecosystems, and biodiversity new horizons for management research. Organization \& Environment, 26, 203-229. 
Wright, C., \& Nyberg, D. (2017). An inconvenient truth: How organizations translate climate change into business as usual. Academy of Management Journal, 60, 1633-1661.

Wright, C., Nyberg, D., Rickards, L., \& Freund, J. (2018). Organizing in the Anthropocene. Organization, 25, 455-471.

Zalasiewicz et al., J. (2016). Working group on the 'Anthropocene.' Retrieved December 19, 2019, from http://quaternary.stratigraphy.org/working-groups/anthropocene/

Zanoni, P., Contu, A., Healy, S., \& Mir, R. (2017). Post-capitalistic politics in the making: The imaginary and praxis of alternative economies. Organization, 24, 575-588.

Zietsma, C., \& Lawrence, T. B. (2010). Institutional work in the transformation of an organizational field: The interplay of boundary work and practice work: Administrative Science Quarterly, 55, 189-221.

\section{Author biographies}

Seray Ergene is an assistant professor of management in the College of Business, University of Rhode Island. Her research explores nature-human relations to advance more-than-human and more-than-capitalist approaches in organization studies.

Bobby Banerjee is a professor of management and Associate Dean of Research and Enterprise at Cass Business School, City University of London.

Andrew Hoffman is the Holcim (US) Professor of Sustainable Enterprise at the University of Michigan, a position that holds joint appointments in the Ross School of Business and School for Environment and Sustainability. 
Table 1. From managerial to critical epistemologies.

\begin{tabular}{ll}
\hline Focus & Managerial Epistemology \\
\hline & $\begin{array}{l}\text { Corporate interests: While environmental and } \\
\text { social issues are important, firms must focu } \\
\text { on their profitability and shareholder wealth } \\
\text { be able to address those issues. }\end{array}$ \\
$\begin{array}{l}\text { Conception of } \\
\text { the natural } \\
\text { environment }\end{array}$ & $\begin{array}{l}\text { Nature is understood as a resource to be } \\
\text { carefully managed and used for economic } \\
\text { growth and business profitability. }\end{array}$
\end{tabular}

Conception of Environmental crisis is an issue to be the ecological managed, and corporations are the main crisis

Imaginary

Corporate sustainability: We can address the crisis by market-based solutions, such as industry self-regulation and clean technology.

\section{Critical Epistemologies}

Ecological wellbeing, local communities, environmental justice: Access to clean water and air, nutrition, and land regardless of wealth and other social disparities among populations.

Nature has its own intrinsic value regardless of how humans value nature. Managing the natural environment is a modernistic ambition that aims to control nature. This is the core premise that created the Anthropocene and its devastating conditions. These ambitions perpetuate anthropocentrism in the name of sustainability.

Ecological crisis is inseparable from political-economy. Anthropocene signal the limits of economic growth and endless production and consumption.

We need to create alternative forms of organizing that channel efforts for restoring and creating livable ecologies for all.

Table 2. From realist to relational ontologies.

\begin{tabular}{lll}
\hline & Realist Ontology & Relational Ontologies \\
\hline World-view & The world is made of stable cause-and-effect & The world is in a continual state of flux and becoming. \\
& $\begin{array}{ll}\text { relationships and objective facts, which are } \\
\text { independent of context and observer. }\end{array}$ & $\begin{array}{l}\text { Entanglements of humans and nonhumans co-create the } \\
\text { world and the conditions in which we live. }\end{array}$
\end{tabular}

Conception of Humans and the natural environment are the natural separate entities. environment

Conception of Realist thinking observes ecological issues the ecological and societal concerns as belonging to distinct crisis domains. While ecological issues are about the natural environment, societal concerns are related to human problems.

Imaginary $\quad \begin{aligned} & \text { Linear approach that isolates environmental } \\ & \text { problems to be solved by organizations. }\end{aligned}$
There is no conceptual separation between humans and the natural environment; humans are part of nature.

Relational view conceives environmental problems as product of human and nonhuman entanglements. From this view, it is not possible to detach environmental issues from societal concerns. Thus, ecological crisis is a web of co-constituted multiple issues that are produced within and through human and nonhuman practices.

Relational approach that requires interventions to be formulated within network of relations of corporations, regulators, civil society, and nonhumans. At its core, relational approach facilitates imagining different humanEarth relations for a more-than-human world. 
Table 3. From discipline-focused to interdisciplinary research.

\begin{tabular}{|c|c|c|}
\hline & Discipline-focused Research & Interdisciplinary Collaborative Research \\
\hline $\begin{array}{l}\text { Purpose of } \\
\text { research }\end{array}$ & $\begin{array}{l}\text { To contribute to management knowledge by } \\
\text { publishing in high-impact and area specific } \\
\text { journals. }\end{array}$ & $\begin{array}{l}\text { To develop climate science literacy and in-depth } \\
\text { understanding of emerging Anthropocene problems. } \\
\text { To bring attention to diverse interests and priorities, } \\
\text { particularly those of disadvantaged populations. }\end{array}$ \\
\hline $\begin{array}{l}\text { Focus of } \\
\text { research }\end{array}$ & $\begin{array}{l}\text { The focus is on organizational phenomena } \\
\text { that take humans and their institutions and } \\
\text { practices as the center of analysis. }\end{array}$ & $\begin{array}{l}\text { The focus is on nature-human ecosystem functioning, } \\
\text { and interdependency of ecological and socio-cultural } \\
\text { systems. }\end{array}$ \\
\hline
\end{tabular}

Table 4. From value-neutral stance to engaged scholarship.

\begin{tabular}{ll}
\hline & Value-neutral Stance \\
\hline Conception of a & The scholar is an expert of knowledge. \\
scholar & S/he is an "objective" observer of the \\
empirical world.
\end{tabular}

Task of a scholar
The scholar is guided by the existing theoretical puzzles in the literature. Accordingly, the scholar's task is to conduct "objective" research that would fill the theoretical gap in the literature.

\section{Engaged Scholarship}

The scholar is a participant of the world. Researcher's personal interests and concerns inform the questions $\mathrm{s} / \mathrm{he}$ asks and the approaches $\mathrm{s} / \mathrm{he}$ employs to gather and analyze data.

The scholar is committed to improving ecological and social conditions. Thus, the task of a scholar is to facilitate social change by aligning research, teaching and service activities with social and environmental justice and ecological wellbeing. 
Table 5. Developing Research Projects for the Anthropocene.

\begin{tabular}{|c|c|c|c|c|}
\hline & Critical Epistemologies & Relational Ontologies & Interdisciplinary Research & Engaged Scholarship \\
\hline Challenges & $\begin{array}{l}\text { Critical view requires questioning } \\
\text { the very assumptions underlying } \\
\text { managerial approach. Yet it is } \\
\text { difficult doing so while } \\
\text { management research and } \\
\text { education is committed to } \\
\text { managerial priorities and corporate }\end{array}$ & $\begin{array}{l}\text { Relational view has not been a } \\
\text { well-established philosophical } \\
\text { position in MOS. To work from } \\
\text { this view, learning new } \\
\text { vocabularies to account for } \\
\text { relationalities and nonhumans in } \\
\text { research is necessary. }\end{array}$ & $\begin{array}{l}\text { There are ontological and } \\
\text { epistemological differences } \\
\text { between natural and social } \\
\text { sciences, and such distinctions } \\
\text { create incompatibilities in research } \\
\text { questions asked and methods } \\
\text { employed. }\end{array}$ & $\begin{array}{l}\text { Dominant positivist tradition seeks } \\
\text { research that is conducted through } \\
\text { objective and disinterested stance. } \\
\text { Tenure and promotion criteria are } \\
\text { based on journal impact factors } \\
\text { rather than contribution to socio- } \\
\text { ecological change in communities. }\end{array}$ \\
\hline
\end{tabular}

interests.

Institutional norms prioritize

disciplinary research in

performance evaluations.

Broad RQs What imaginaries do existing sustainability solutions forward?

How do they transform

What does management and organization studies look like, as we challenge the conceptual separation of humans and exploitative power relations, be it capitalist, patriarchal, colonial and others?

Are they sufficient to address unequal effects of the Anthropocene conditions on already disadvantaged populations?

nonhumans?

Who/what is the subject/object of management and organization studies?

What different human-Earth relations can emerge as we challenge humans' superiority to the rest of nature?

What's next? Critically analyze existing market Learn to observe relationalities, solutions from the perspectives of assemblages and entanglements, non-corporate constituents, including nonhumans. Study diverse forms of organizing to draw insights into conceptualizing viable alternatives to current dominant forms.

What issues do natural scientists prioritize, and how can these priorities be translated and studied in management and organization studies?

How do natural scientists approach common Anthropocene problems such as biodiversity loss, food insecurity, lack of access to clean water, plastics pollution?

Articulate and develop a repertoire of practices and processes in collaborating with natural scientists.

Create a common language across disciplinary boundaries.
How do we establish connections and gain trust of various

stakeholders?

How do policy-makers, NGOs, and civil society make decisions for common concerns and public interests? and design research studies that

focus analytic attention on the

agencies of webs of relations of

humans and nonhumans.
Learn to see practitioners as collaborators and research partners who pursue mutual interests and concerns with the researcher.

Reflect on the roles of academics as one transforms into a "politically engaged scholar". 